\title{
A technological innovation systems approach to analyse the roles of intermediaries in eco- innovation
}

Wisdom Kanda, Pablo del Río, Olof Hjelm and Dzamila Bienkowska

The self-archived postprint version of this journal article is available at Linköping University Institutional Repository (DiVA):

http:/ / urn.kb.se/ resolve?urn=urn:nbn:se:liu:diva-156962

N.B.: When citing this work, cite the original publication.

Kanda, W., del Río, P., Hjelm, O., Bienkowska, D., (2019), A technological innovation systems

approach to analyse the roles of intermediaries in eco-innovation, J ournal of Cleaner Production, 227,

1136-1148. https:// doi.org/ 10.1016/j.jclepro.2019.04.230

Original publication available at:

https:// doi.org/ 10.1016/j.jclepro.2019.04.230

Copyright: Elsevier

http:// www.elsevier.com/

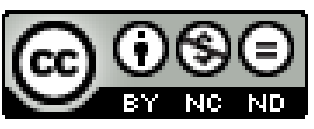


A technological innovation systems approach to analyse the roles of intermediaries in ecoinnovation

Wisdom Kanda ${ }^{1 *}$, Pablo del Río ${ }^{2}$, Olof Hjelm ${ }^{1}$ and Dzamila Bienkowska ${ }^{3}$

${ }^{1}$ Environmental Technology and Management, Department of Management and Engineering, Linköping University, SE-581 83 Linköping, Sweden.

${ }^{2}$ Institute for Public Policies and Goods, Spanish Council for Scientific Research (CSIC), C/Albasanz 26-28, 28037 Madrid, Spain.

${ }^{3}$ Project, Innovation and Entrepreneurship, Department of Management and Engineering, Linköping University, SE-581 83 Linköping, Sweden.

*Corresponding author: E-mail address: wisdom.kanda@liu.se Tel.: +46 (0)13281696

\begin{abstract}
The literature on intermediaries faces challenges regarding how to conceptualise and empirically demonstrate the system-level impact of intermediaries. Thus, researchers and policy analysts may experience difficulties in grasping the potential contributions of intermediaries beyond individual projects and firms to aggregate levels of an innovation system. This article combines innovation intermediary and technological innovation systems literature to develop fundamentals of an approach for analysing how organisations acting as intermediaries support firms in eco-innovation and potentially contribute to technological innovation system functions. The operationalisation of the analytical approach is illustrated using case studies on a total of eight support organisations acting as intermediaries in the region of Scania, Sweden and North Rhine Westphalia, Germany. For researchers and policy analysts, the analytical approach presented in this article offers the opportunity for a step-bystep, comprehensive and transparent analysis of different types of intermediaries, their roles, and potential contributions to innovation system functions.
\end{abstract}

Keywords: Impact assessment; Sustainability transitions; Intermediation; Eco-innovation intermediaries; Circular Economy. 


\section{Introduction}

In the wake of contemporary environmental problems such as climate change, there is increasing pressure from policy makers and consumers on businesses to improve the environmental performance of their processes and offerings. To this end, eco-innovations, broadly defined as innovations that improve environmental performance of production and consumption activities from a life cycle perspective with or without intention are essential (Carrillo-Hermosilla et al., 2010). In this line of thought, the research stream on ecoinnovation is emerging to consolidate a new paradigm that environmental problems also represent opportunities for businesses to discover, create and exploit new products and services which sustain the natural environment and contribute to social welfare (Cohen and Winn, 2007). Despite the potential benefits for businesses to engage in eco-innovation, for example cost savings through increased energy and material efficiency which are in-line with current circular economy principles (cf. Geissdoerfer et al., 2017), realising competitive and strategic advantages through successful new products or services (Horbach, 2008), business activities focused on tackling environmental problems through innovation are challenging and can be stifled by market and system failures (Bleda and del Río, 2013).

Eco-innovators face particular challenges such as the "double externality" problem (Rennings, 2000), the dependence on regulations (e.g. tax exemptions, subsidies) in addition to resource limitations encountered by innovators in general (Hojnik and Ruzzier, 2016). An "externality" is an economically significant effect of an activity, the consequences of which are borne (at least in part) by a party or parties other than the party that controls the externality producing activity (Jaffe et al., 2005). Thus, an externality can be labelled as negative when a party deciding does not have to pay the full cost of the decision while a positive externality is a benefit enjoyed by a party as a result of an economic activity they have not directly paid for. An important characteristic of eco-innovations is that they produce positive externalities both in the innovation and diffusion phase - i.e. "double externality" (Rennings, 2000). In the innovation phase, there are positive externalities regarding research and development efforts of firms, while in the diffusion phase, positive externalities appear due to the smaller amount of external costs associated with eco-innovations compared to competing products and services on the market. Since businesses, in particular small and medium sized enterprises (SMEs), may not have all the resources to tackle some of these challenges, they often need linkages to support actors outside their organizational boundaries to access essential resources (e.g. knowledge, networks, finances) to complement their internal resources, capabilities and competences to eco-innovate (Hjelm and Lindahl, 2016).

Recent literature highlights the relevance of both internal and external factors for firm-level eco-innovation (Kiefer et al., 2018). Some literature further points to the particular intensity of cooperation across organizational borders in eco-innovation compared to other innovation due to the systemic and complex character of eco-innovations (De Marchi, 2012). This is inferred from the presence of interdependencies on knowledge, skills and resources as well as the need to complement internal firm resources with competences from different domains during eco-innovation (Marzucchi and Montresor, 2017). We refer to support organizations which assist firms in the eco-innovation process by providing different types of support often by acting as a broker or bridge between two or more parties as eco-innovation intermediaries ${ }^{1}$. These intermediaries are an integral part of the support system for eco-innovators which comprises "all actors, institutional settings and resources that help entrepreneurs in successfully generating and implementing innovation" (Fichter et al., 2013 p.75)

\footnotetext{
${ }^{1}$ See section 2.1 for a discussion on the roles of intermediaries.
} 
The activities of intermediaries in eco-innovation and sustainability transitions in general continues to receive scholarly attention (see Gliedt et al., 2018; Kivimaa et al., 2019 for recent reviews). Howells (2006) synthesised ten roles of intermediaries in innovation in general. For eco-innovation, there is an extant literature on how different types of actors support their development and diffusion (see e.g. del Río et al., 2016 for a review). For intermediaries in particular, Klewitz (2012) identified the roles they can play in SMEs' pursuit of corporate sustainability with a focus on eco-innovation. Polzin et al., (2016) analysed how intermediaries can use their financial resource mobilization roles to address some barriers along the eco-innovation process. Kivimaa et al., (2017) examined the roles of intermediaries in the commercialization of eco-innovations with a focus on a university innovation ecosystem. Finally, in a recent contribution, Kanda et al., (2018) provided a synthesis of the different roles intermediaries assume in eco-innovation and in particular highlighted how these roles differ from intermediation in innovation.

With the increasing scholarly contributions on intermediaries, some related methodological and conceptual challenges remain to be addressed. First, the organisations, actors and platforms studied as intermediaries are heterogenous and very diverse, which poses challenges regarding the generalizability of findings from one study to the other (Mignon and Kanda, 2018). Second, there is sometimes redundancies and confusion regarding the roles of intermediaries in (eco)-innovation (Klerkx and Leeuwis, 2009). Third, previous literature has focused extensively on the roles of intermediaries and how they generate value for their clients (De Silva et al., 2018), with little insight on the contribution of intermediaries to the broader innovation system. These challenges can be attributed to the different types of entities studied as intermediaries, their different characteristics and the different contexts within which they operate. Furthermore, previous studies on intermediaries have widely different starting points and conceptual foundations (Howells, 2006). These are important challenges since the lack of transparency and clarity regarding these aspects in some previous studies means that it can be challenging for researchers to make robust recommendations for practitioners regarding what to expect from different types of intermediaries.

To address these research gaps, the article develops fundamentals of an approach for analysing the roles of intermediaries in eco-innovation and also provides early thoughts on how to assess the system-level impact of intermediaries beyond projects and firms. The approach is operationalised in the region of Scania, Sweden and North Rhine Westphalia Germany to analyse how organizations acting as intermediaries may support firms in the development of eco-innovations. The rest of the article is structured as follows: In Section 2, we discuss previous literature on innovation intermediaries and technological innovations systems, which serves as a basis for developing the analytical approach. The analytical approach including methodological choices and considerations are presented in Section 3. In Section 4, we operationalize the analytical approach using empirical case studies. A discussion on the application of the analytical approach to our empirical cases is provided in Section 5. Furthermore, we complement this empirical focused discussion with reflections on how the analytical approach works and what needs to be improved. Section 6 focuses on conclusions and further research directions. 


\section{Intermediaries and Technological Innovation Systems}

\subsection{Intermediaries' support for (eco)-innovation}

Previous literature on intermediaries can be grouped into several categories. One categorisation is by the type of innovation which the intermediaries facilitate. Some scholars focus on intermediaries in innovation in general (e.g. Howells, 2006), while others focus on intermediaries facilitating specific categories of innovations e.g. eco-innovation (e.g. Polzin et al., 2016). SMEs are important candidates for developing and diffusing eco-innovations because of their characteristics such as flexibility and lean organizational structures (Keskin et al., 2013). However, such firms face challenges such as addressing multiple goals in innovation (e.g. environmental, economic and social), difficulty in creating customer value based on eco-innovations and inability to internalise all benefits of the innovation process (ibid). Furthermore, eco-innovation can be a complex and challenging activity for many SMEs due to resource constraints in terms of personnel, knowledge and financial capital (Klewitz et al., 2012). Other managerial and structural challenges mean that sometimes ecoinnovation and sustainability issues are dealt with in a marginal way, with little or no personnel commitment using ad hoc informal approaches (ibid). The eco-innovation process in itself can be more complex than innovation in general since eco-innovation requires combination of different domains of knowledge and collaborating with different actors along the value chain (De Marchi, 2012).

Thus, cooperation with external public, private and non-governmental actors and organizations is deemed particularly important to increase the eco-innovative capacity of SMEs (Kanda et al., 2018). And cooperation has been shown to be a main driver for ecoinnovation and, in particular, consistent government support is regarded as a significant enabler for developing and diffusing eco-innovations (del Río et al., 2016). This can be attributed to the limited interest of private actors to act as catalyst for eco-innovations due to both market and system failures. Thus, publicly-owned intermediaries have been found to provide an alternative complementary role to private intermediaries, whose actions are typically profit-driven (Kivimaa, 2014). Different types of entities, for example, universities, incubators, science parks, cluster initiatives, project developers, and business development organizations have been identified as support actors which assist firms in (eco)-innovation often by acting as brokers between two or more parties (Howells, 2006).

An overarching objective of intermediaries in eco-innovation is to assist firms in the development, diffusion and uptake of (eco)-innovations. Thus, intermediaries in ecoinnovation undertake different activities with the intention to validate the environmental benefits of eco-innovations and to assist eco-innovators to internalise the positive externalities in the development and diffusion of eco-innovations (Kanda et al., 2018). The support activities offered by such organisations have been conceptualised into several categories in the literature. For example, Howells (2006) synthesized ten roles of intermediaries in innovation as: foresight and diagnostics; scanning and information processing; knowledge processing and combination/recombination; gatekeeping and brokering; testing and validation; accreditation; validation and regulation; protecting the results; commercialisation; evaluation of outcomes. For eco-innovation, Kanda et al., (2018) synthesized eight roles of intermediaries such as: forecasting and road mapping, information gathering and dissemination, fostering networking and partnerships, prototyping and piloting, technical consulting, resource mobilization, commercialization, and branding and legitimation. Furthermore, the authors argue that the roles of intermediaries such as financial resource mobilization for companies in the early phases of innovation and also aggregating the views 
of different actors to influence institutions are particularly relevant for eco-innovations due to the double externality challenge and the influence of policy.

\subsection{Technological Innovation Systems (TIS)}

The innovation systems literature (for an overview, see Carlsson et al., 2002), argues that innovations are developed and diffused within a technological, sectorial, geographical and political context. The approach focuses on the dynamic interactions between actors, networks, and institutions in the generation and diffusion of innovations. And as a basic requirement, these core elements co-evolve over time and need synergies in order to successfully generate and diffuse innovations. The literature adopts a systemic approach to innovation and builds on concepts such as path dependency, interdependency, feedback loops, and co-evolution (Markard and Truffer, 2008). This approach can inform how innovation emerge in particular contexts, what system failures may arise and how innovation may be influenced by formal and informal institutions (Foxon and Andersen, 2009).

A particularly relevant approach within the innovation systems literature is the technological innovation system (TIS), which is based on evolutionary theorizing and systems theory (Markard, 2018). A TIS refers to a dynamic socio-technical system of actors, and their networks whose interactions are guided by formal and informal institutions with an overarching aim to develop and implement particular technologies (Carlsson and Stankiewicz, 1991). To analyse the performance of TIS systems, the literature suggests a set of key system functions which need to be performed at a certain level of quality (Bergek et al., 2008; Hekkert et al., 2007). The literature further argues that, in order to understand the emergence and implementation of innovations, analysing the current structure of the innovation system is not sufficient but, rather, an understanding of the activities that take place within the system functions - over time is necessary. Functions are emergent properties of the interplay between actors and institutions (Markard and Truffer, 2008). And several technological system functions are identified in the previous literature (see Table 1). The assessment in terms of system functions is one of the main approaches of the TIS approach which we borrow into this article, since it allows us to provide early thoughts on how to assess the system-level contributions of intermediaries beyond individual projects and firms. In particular, the TIS functions provide a dynamic set of activities onto which we can map intermediary roles.

Table 1. Functions of Technological Innovation Systems.

\begin{tabular}{|l|l|}
\hline Function & Description \\
\hline $\begin{array}{l}\text { 1. Knowledge } \\
\text { development and } \\
\text { diffusion }\end{array}$ & $\begin{array}{l}\text { This function depicts the development, diffusion and combination of knowledge } \\
\text { within the technological innovation system. }\end{array}$ \\
\hline $\begin{array}{l}\text { 2. Guidance of the } \\
\text { search }\end{array}$ & $\begin{array}{l}\text { This function refers to activities within the innovation system that can positively } \\
\text { influence the visibility and clarity of the specific needs of technology users. }\end{array}$ \\
\hline $\begin{array}{l}\text { 3. Entrepreneurial } \\
\text { experimentation }\end{array}$ & $\begin{array}{l}\text { This function refers to the activities of entrepreneurs to explore new knowledge, } \\
\text { networks and markets into concrete actions and in doing so generate new business } \\
\text { opportunities. }\end{array}$ \\
\hline $\begin{array}{l}\text { 4. Market } \\
\text { formation }\end{array}$ & $\begin{array}{l}\text { Refers to activities that are undertaken to create markets for new innovations such } \\
\text { as the formation of temporary niche markets and the creating competitive } \\
\text { advantage for innovations through favourable tax regimes. }\end{array}$ \\
\hline $\begin{array}{l}\text { 5. Development } \\
\text { of positive } \\
\text { externalities }\end{array}$ & $\begin{array}{l}\text { This function captures the entrance of new actors into the TIS and its benefits for } \\
\text { other actors or sectors. }\end{array}$ \\
\hline 6. Legitimation & $\begin{array}{l}\text { The function essentially captures activities to counteract the resistance to change } \\
\text { upon introduction of an innovation. Legitimacy is an issue of social acceptance and } \\
\text { compliance with relevant formal and informal institutions. }\end{array}$ \\
\hline
\end{tabular}




\begin{tabular}{|l|l|}
\hline $\begin{array}{l}\text { 7. Resource } \\
\text { mobilization }\end{array}$ & $\begin{array}{l}\text { This function captures mobilization of resources such as human and financial } \\
\text { capital, and other complementary resources needed for the proper functioning of } \\
\text { the innovation system. }\end{array}$ \\
\hline
\end{tabular}

Source: adapted from (del Río and Bleda, 2012) based on (Bergek et al., 2008; Hekkert et al., 2007; Markard and Truffer, 2008).

System functions interreact with each other and build synergies over time needed to strengthen the market penetration of new innovations and for technological innovation systems to form (Hekkert and Negro, 2009). The TIS approach emphasises the importance of interactions between different system actors in fostering innovation. Thus, a key issue in the TIS approach is how supporting actors can facilitate innovation by adopting intermediary roles within the system (Nilsson and Sia-Ljungström, 2013).

The TIS approach is connected to the transition literature and, particularly, to the multilevel perspective (MLP). The MLP views transitions as non-linear processes that result from the interplay of developments at three analytical levels: niches (the locus for radical innovations), socio-technical regimes (the locus of established practices and associated rules that stabilize existing systems), and an exogenous sociotechnical landscape. Each 'level' refers to a heterogeneous configuration of elements; 'higher' levels are more stable than 'lower' levels in terms of number of actors and degrees of alignment between the elements (Geels, 2011, p. 26). The TIS focuses on the niche and regime levels whereas the MLP also emphasizes the role of landscape factors and changes in the socio-technical landscape (e.g. climate change or peak oil). Intermediaries act particularly within and in-between niches and regimes assuming different roles to facilitate sustainability transitions in general (Kivimaa et al., 2018).

\subsection{Linking functions thinking from TIS to intermediaries' support roles}

As outlined in the introduction, some of the emerging challenges in the innovation intermediary literature relate to the need for methodological and conceptual advancements in order to generate transparent and policy relevant contributions. Scholarly contributions have been made in the TIS literature which are particularly relevant to draw lessons which can be applied to the innovation intermediary literature. Indeed, interest in the role of intermediaries in the innovation process has emerged from different sources and research fields, including the systems of innovation literature (Howells, 2006). It is the "functions" thinking which makes the TIS approach particularly relevant for the innovation intermediary literature since connections can be made between the roles of intermediaries in innovation and TIS functions (Lukkarinen et al., 2018). To the innovation intermediary literature, the functional approach adopted in this article advocates for consensus building and clarity regarding the different types of intermediaries, and their roles. Establishing such a link would enable researchers to further explore contributions of innovation intermediaries to several of the innovation system functions, an issue which has been advocated by Kivimaa (2014) and beginning to emerge in the literature (e.g. Lukkarinen et al., 2018).

Indeed, there is an overlap between the key roles of innovation intermediaries and the functions of technological innovation systems. In both bodies of literature, there is a considerable emphasis on generating and disseminating knowledge and information among actors. There is also a shared realisation on the centrality of scanning and identifying future opportunities, visions, and brokering and matchmaking between actors to form networks and partnerships. However, according to Nilsson and Sia-Ljungström (2013), a significant difference between both literatures is, however, that in research focusing on innovation intermediaries, there is a strong emphasis on supporting stages in the innovation process (which suggests a linear conceptualisation to the innovation process), while the innovation 
systems literature adopts a systemic approach to innovation. While there is currently no benchmarking tool for measuring the performance of the intermediaries, the functions perspective for the innovation system can be considered as a way of evaluating the systemlevel performance of an intermediary within an innovation system. In this article we conduct an ex ante analysis of how intermediaries can contribute to the TIS functions. This represents preliminary steps to analyse the potential system-level impact of intermediaries in innovation systems. Future research efforts could be dedicated to assess whether the intermediaries have contributed to the fulfilment of TIS functions, i.e. their actual performance in a particular setting (ex-post analysis).

\section{The analytical approach}

The analytical approach (see Figure 1) is inspired by the TIS functions approach (see Bergek et al., 2008), the roles of innovation intermediaries in (eco)-innovation (e.g. Howells, 2006; Kanda et al., 2018) and the eco-innovation literature (e.g. Carrillo-Hermosilla et al., 2010). The approach was developed iteratively, with insights from the scientific literature, discussions with experts in the innovation system and also experiences from our empirical case studies on intermediaries. The following sub-section provides details on the various steps, including methodological considerations and choices available for the analyst. The approach is presented step-by-step for the sake of clarity, although in practise, iterations and feedback loops are common.

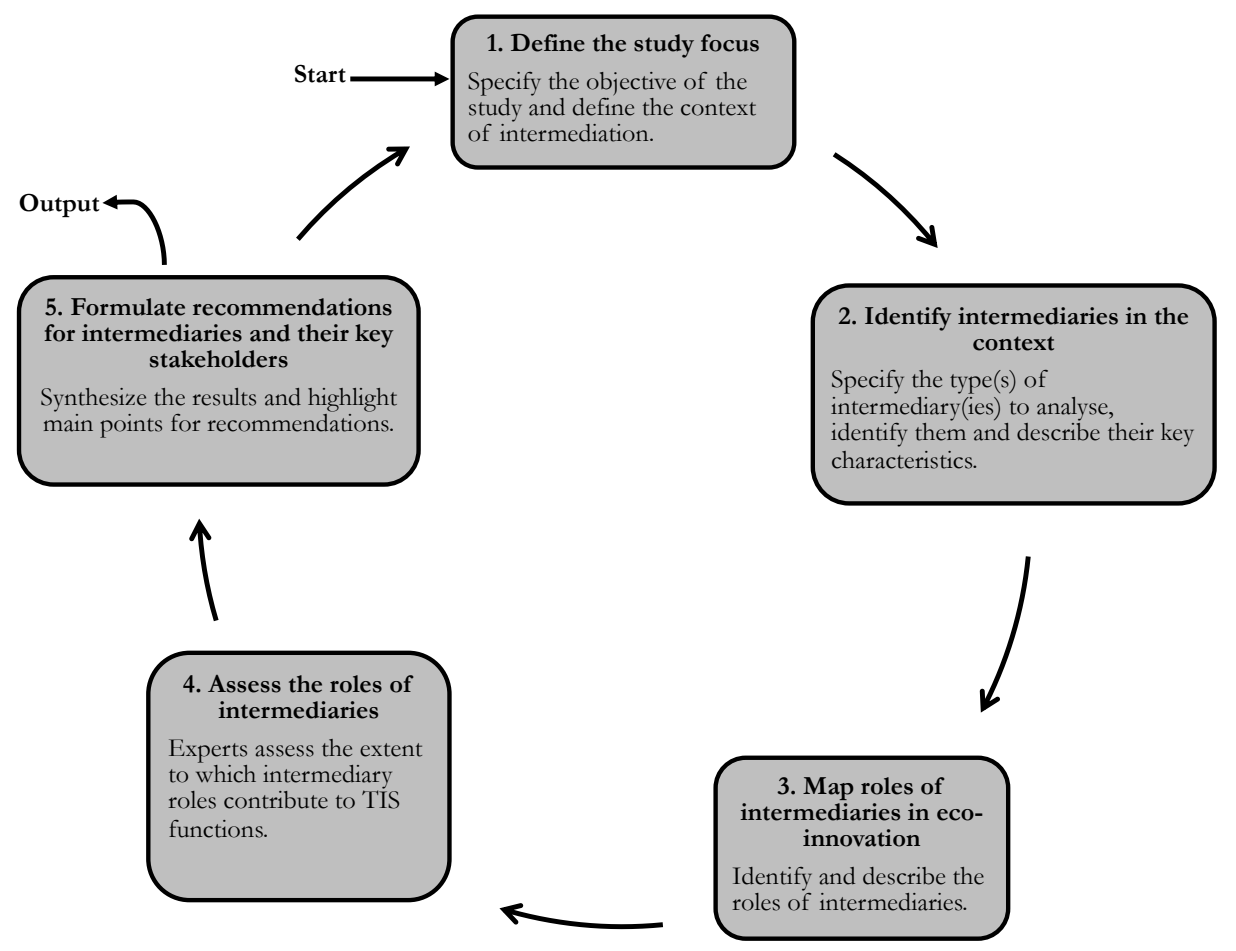

Figure 1. An analytical approach to assess the roles of intermediaries in eco-innovation. Source: authors' elaboration with inspiration from (Bergek et al., 2008). 


\section{Step 1: Defining the study focus}

The first step in the analytical approach is to define the focus of the study. This requires the analyst to: (i) specify the objective of the study, and (ii) define the context of intermediation. Clearly specifying the objective of the study gives guidance regarding the different methodological choices to make and their implications. Furthermore, a clear definition of the intermediation context ensures that the study is consistent with its starting objectives, and also transparent. Though it is suggested that the context of intermediation should be defined early in the analysis, it can be refined as the study progresses and the boundaries of the case become clearer, following an empirical in-depth analysis and understanding. Whereas defining the objective of the assessment could be relatively straight forward, defining the context within which the intermediary operates could be rather challenging.

Intermediaries operate in and between different contexts. Urban transition studies e.g. Coenen and Díaz López (2010), offer a spatial perspective in which intermediation occurs between national, regional and city scales. In this context, intermediation at the local level may seek to complement or challenge the national innovation system through aggregation activities and acting as a common voice for several local actors (Lukkarinen et al., 2018). Another intermediation context often highlighted in the intermediary literature is a distinction between intermediaries working on the system level and those who focus on intermediating between individual entities such as projects, companies, consumers, and producers (Mignon and Kanda, 2018). While system level intermediation is more strategic and tends to generate benefits for a broader base of actors and their networks through, for example, the articulation of visions, and policy renewal, intermediating between individual entities is aimed at directly supporting individual entities through bilateral relations (van Lente et al., 2003). Intermediaries broker and manage partnerships between different projects and other actors from outside the projects. In this position, intermediaries are particularly important in increasing the public acceptance for innovations through policy advocacy and mobilizing policy support for particular innovations (Smith et al., 2016). In-between consumers and producers, intermediaries are involved in the adaptation and adjustment of innovations to fit the particular contexts within which they are adopted (Hyysalo et al., 2017). Thus, a careful definition of the intermediation context is important to restrict the number of plausible explanatory factors regarding the contribution of intermediaries to innovation systems and it also allows for the comparison of different studies.

\section{Step 2: Identify intermediaries in the context}

After defining the focus of the study, the identification of intermediaries which are relevant for eco-innovations represents the next logical step. Therefore, Step 2 focuses on identifying and describing intermediaries within the focus of the study. A particular challenge for the analyst is how to identify an intermediary in practise. Even though there are definitions in the literature for an intermediary, e.g. "an organization of body that acts as an agent or broker in any aspect of the innovation process between two or more parties" (cf. Howells, 2006 p.720), the label as an intermediary is not static. Some entities are strategically set-up to intermediate and have a majority of their activities focused on intermediation, while others emerge to assume intermediation roles occasionally. Yet, there are also entities which may not recognize their status as intermediaries. Consequently, the scientific literature lacks consensus on how intermediation is defined, where it begins and ends, and thus the term covers a wide range, from formal self-recognised forms to informal and mostly hidden forms of intermediation (Kivimaa et al., 2018). These differences notwithstanding, intermediaries are often identified by the roles they perform in different processes, their relational work and their positioning in- 
between other entities e.g. actors, projects, technologies (Moss, 2009). Intermediaries can have a general "neutral" focus (supporting all kinds of innovations) or specific "normative" focus (supporting particular eco-innovations). Intermediaries can be platforms, individuals, groups or organizations with public, private or non-governmental affiliation. These different types of intermediaries are accessible to eco-innovators and should be identified for further analysis based on the objective of the assessment.

The objective of the assessment could make it recommendable for the analyst to focus on a particular type of intermediary or a group of intermediaries. Mignon and Kanda (2018) identified ownership, source of funding, scope of action and target recipients as aspects of intermediaries which affect their longevity, the potential impact of their intermediation and the phase of innovation within which they inter-mediate. Thus, it is important to make explicit the characteristics of the identified intermediaries. The identification of intermediaries within a defined scope can be based on existing knowledge and literature. Relevant methods include interviews, discussions with industry experts and firms that have received support from intermediaries, and review of information from industry associations. Another approach is to use visualization workshops where selected stakeholders would be asked to map the different intermediaries within the defined scope. When a sufficient number of intermediaries has been identified with no new actors emerging, the maps of the different actors are combined to form an overall intermediary map within a given scope. Often, these different methods can be used in combination to develop a comprehensive map and offset their inherent limitations. The intermediary mapping could have different levels of actor resolution depending on the objectives of the assessment, but it should be detailed enough in order for important actors and their interactions to be visible.

\section{Step 3: Mapping roles of intermediaries}

In Step 3, the support roles of intermediaries in eco-innovation are identified and described. Intermediary roles refer to all actions and activities of intermediaries intended to assist firms in the development, diffusion and adoption of eco-innovations. In identifying and describing the roles of the intermediaries, the suggested procedure is for the analyst to conduct interviews and documentation studies (e.g. project portfolios, printed or electronic publications, news releases) on the intermediaries identified and their stakeholders. After obtaining comprehensive data, the analyst can identify typologies of intermediation roles in the literature to relate to based on the study's objective and conceptual foundations (see e.g. Howells., 2006; Kivimaa, 2014; and Kanda et al.,2018). A particular confusion in this process is that the current literature on innovation intermediaries is redundant with various roles attributed to intermediaries in innovation. This is because the different studies are not always explicit regarding the type of intermediary studied and their context. Furthermore, studies on innovation intermediaries have widely different starting points and conceptual foundations (Howells, 2006). To assist the analyst in dealing with this challenge, it is suggested to rigorously specify which types of intermediaries are studied, their scope and context of intermediation.

\section{Step 4: Assessing the potential roles of intermediaries in eco-innovation}

An assessment of the potential roles of intermediaries is necessary in order to provide recommendations to intermediaries and their key stakeholders, such as owners, funders and clients. At this stage, the analyst has a good overview of the intermediary actors, their key stakeholders and a description of their roles in eco-innovation. However, the previous steps in the analytical approach do not give insights as to how intermediation contributes to the broader innovation system and its overall function of developing and diffusing innovations. 
Based on insights from the reviewed literature and also from our case studies, we propose that the support roles of intermediaries should be accessed based on their potential contribution to the TIS functions. A theoretical connection between the roles of intermediaries and the TIS functions is provided in Table 2.

The potential contributions of intermediaries to the functions apply also to innovation in general. However, Table 2 shows the roles of intermediaries for eco-innovation in particular. This "added contribution" is related to the specific features of eco-innovation compared to general innovation: its environmental attributes and, thus, lower environmental externalities (Rennings, 2000), and the role of regulation and cooperation with other stakeholders as more relevant drivers (De Marchi, 2012). Thus, intermediaries can play a specific role in ecoinnovation: to validate the environmental benefits of eco-innovation (i.e., demonstrating the environmental benefits of eco-innovation for the general public) or to tackle the environmental externalities (by supporting and influencing environmental policy changes) (Kanda et al 2018).

The specific role of intermediaries in eco-innovation materialises through particular actions which contribute to specific functions. A main one is knowledge resource mobilization and distribution (functions 1 and 7). Information and skills such as eco-design and life cycle thinking, which are required to develop products and services with lower environmental impacts, are often different from the traditional knowledge base available in industry (Kanda et al 2018, p.1013). Prototyping and piloting, information gathering and dissemination and branding are deemed particularly useful to validate the environmental benefits of ecoinnovations (functions 1 and 4). Intermediaries can connect the targeted company with sustainability-oriented organizations, which can provide eco-innovation specific knowledge (Kivimaa et al., 2017).

Intermediaries with a proactive approach can act as important external stimuli for firms, especially those who do not perceive the benefits of sustainability issues in general and adopt a reactive approach to sustainability (Klewitz et al., 2012). This is why intermediaries supporting the use of triple-bottom-line or Life Cycle Analysis (LCA) for strategic planning and decision making can indirectly play a role in the uptake of eco-innovation, e.g. by impacting functions 2 (guidance of the search) and 3 (entrepreneurial experimentation).

In addition, intermediaries can play a relevant role in contributing to function 6 (legitimation) by using different means to create a distinct brand and social acceptance and compliance with relevant institutions for eco-innovation (Kanda et al 2018, p.1010). This is key in the case of eco-innovation, given its specific environmental attributes. In turn, legitimation contributes to mobilize financial, human capital and knowledge resources (function 7), to increase customers' trust and encourage purchasing decisions and to convince policy makers and businesses to give their support to the eco-innovation (market creation, function 4) (Kanda et al 2018, p.1013). Note that some roles affect functions which, in turn, influence other functions (indirect effects).

Table 2. Potential contribution of roles of intermediaries to TIS functions. Based on Lukkarinen, et al. (2018), Kivimaa (2014), Howells (2006), Nilsson and Sia-Ljungström (2013) and Kanda et al., (2018). 


\begin{tabular}{|c|c|}
\hline System Functions & Intermediary roles \\
\hline $\begin{array}{l}\text { 1. Knowledge } \\
\text { development and } \\
\text { diffusion }\end{array}$ & $\begin{array}{l}\text { In general, knowledge gathering, processing, generation and re-combination; } \\
\text { scanning, communication and dissemination of knowledge; education and } \\
\text { training; provision of advice and training, technology assessment and } \\
\text { evaluation. Prototyping and piloting, information gathering and } \\
\text { dissemination and branding are targeted at validating the environmental } \\
\text { benefits of eco-innovations. Connections with sustainability-oriented } \\
\text { organizations which provide eco-innovation specific knowledge. }\end{array}$ \\
\hline $\begin{array}{l}\text { 2. Guidance of the } \\
\text { search }\end{array}$ & $\begin{array}{l}\text { Articulation of needs, expectations and requirements; strategy development; } \\
\text { advancement of sustainability aims; policy implementation, foresight and } \\
\text { diagnosis, identification of problems and opportunities. Using triple-bottom- } \\
\text { line or Life Cycle Analysis (LCA) for strategic planning and decision } \\
\text { making. }\end{array}$ \\
\hline $\begin{array}{l}\text { 3. Entrepreneurial } \\
\text { experimentation }\end{array}$ & $\begin{array}{l}\text { Creating conditions for learning by doing and using. Testing, validation and } \\
\text { training. Using triple-bottom-line or LCA for strategic planning and decision } \\
\text { making. }\end{array}$ \\
\hline 4. Market formation & $\begin{array}{l}\text { Acceleration of the application and commercialisation of new technologies; } \\
\text { prototyping and piloting; investment in new businesses. Identification of } \\
\text { business opportunities. Prototyping and piloting. }\end{array}$ \\
\hline $\begin{array}{l}\text { 5. Development of } \\
\text { positive } \\
\text { externalities }\end{array}$ & $\begin{array}{l}\text { Supporting the entry of new actors in the TIS, which may contribute to a } \\
\text { process whereby the functional dynamics of the TIS are strengthened, } \\
\text { benefiting other members of the TIS. As argued by Bergek et al ( } 2008, \\
\text { p. } 418) \text {, "this function is thus not independent, but works through } \\
\text { strengthening the other six functions". }\end{array}$ \\
\hline 6. Legitimation & $\begin{array}{l}\text { Gatekeeping and brokering; regulation (formal, informal and self- } \\
\text { regulation), configuring and aligning interests; technology assessment and } \\
\text { evaluation; arbitration based on neutrality and trust; accreditation and } \\
\text { standard setting. Evaluating broader societal environmental and social } \\
\text { impacts. Using different means to create a distinct brand and social } \\
\text { acceptance and compliance with relevant institutions for eco-innovation and } \\
\text { the environmental goods and services sector }\end{array}$ \\
\hline $\begin{array}{l}\text { 7. Resource } \\
\text { mobilization }\end{array}$ & $\begin{array}{l}\text { Creation and facilitation of new networks; management of financial } \\
\text { resources; identification and management of human resource needs (skills); } \\
\text { organisation of training programs, project design, management and } \\
\text { evaluation, marketing, support and planning, sales network and selling, } \\
\text { finding potential capital funding and organising funding or offerings. }\end{array}$ \\
\hline
\end{tabular}

It should be noted that the potential linkage between the roles of the intermediaries and TIS functions is conceptual (though some empirical cases support the linkage). Furthermore, a TIS consists of actors, networks and institutions, while intermediaries are often actors and platforms within an innovation system. Thus, the functions of TIS and the roles of intermediaries are on different analytical levels and this article contributes to the debate on how to conceptualise and access the impact of intermediaries beyond projects and companies on innovation system levels by linking those two levels.

Methodologically, it is recommended that an expert panel is used in order to assess the contribution of intermediaries to TIS functions. This is because at the moment it is challenging to evaluate the linkage between intermediary roles and TIS functions based solely on quantitative measurements. The reason is that intermediaries have different characteristics (e.g. capacity, mandate, normative position) and operate in different contexts and thus it is challenging to define an optimal level of contribution from intermediaries to TIS functions and also to benchmark different contributions. Therefore, a plausible method for the assessment is to involve a sufficient number of experts from the innovation system by asking them specific questions. The collective approach builds on the understanding that there are 
different views regarding the definition of the problem, framing and what approaches are appropriate. Thus, sharing knowledge between different stakeholders is deemed a suitable approach for the assessment. For each intermediary role (mapped in Step 3), the experts evaluate their contributions to a particular TIS function based on the aforementioned indicators pertaining to a specific function. This can be done using a qualitative scale of "strong", "medium", "weak" and "not detected" as defined in Table 3.

Table 3: Scales for assessing the contribution of intermediation roles to TIS functions

\begin{tabular}{|l|l|}
\hline Value & Scale definition \\
\hline Strong & $\begin{array}{l}\text { The roles of the intermediary contribute to the fulfilment of most aspects of a } \\
\text { particular system function. }\end{array}$ \\
\hline Medium & $\begin{array}{l}\text { The roles of the intermediary contribute to the fulfilment of many aspects of } \\
\text { a particular system function. }\end{array}$ \\
\hline Weak & $\begin{array}{l}\text { The roles of the intermediary contribute to the fulfilment of a few aspects of a } \\
\text { particular system function. }\end{array}$ \\
\hline Not detected & $\begin{array}{l}\text { The intermediary has no detectable roles connected to aspects of a particular } \\
\text { system function. }\end{array}$ \\
\hline
\end{tabular}

\section{Step 5: Recommendations for intermediaries and their key stakeholders}

In the final step, the focus is to provide relevant recommendations for intermediaries and their key stakeholders. The recommendations should be based on identified weaknesses and deficiencies in the current intermediation roles with respect to the TIS functions. In addition, strengths identified from the assessment would also be valuable for the sharing of experiences and lessons learned. Though the functional thinking is at the core of this assessment, other structural characteristics of intermediaries can be of importance for improvement. For example, the source and stability of funding for intermediaries is particularly influential on their impact since it determines whether they focus on advancing the objectives of the parties in-between which they mediate or seek their own interest for survival and longevity.

\section{Example: analysing the potential roles of intermediaries to support eco-innovation in the region of Scania and North Rhine Westphalia}

To illustrate the operationalisation of the analytical approach, we concisely applied the approach to eight case studies of intermediaries supporting firms in eco-innovation in the region of Scania, Sweden and North Rhine Westphalia, Germany. This operationalisation is to serve as an illustrative example of our approach and does not aim to undertake an elaborate analysis of the cases nor to validate the analytical approach. Finally, our illustration does not include step 5, recommendations for the studied intermediaries and their key stakeholders, but rather we discuss the case studies and provide general lessons for the broader scientific audience.

\section{Step 1 - Define the study focus}

The objective of our illustrative study was to analyse the roles of intermediaries in supporting firms developing and or adopting eco-innovations. We adopted a regional scope since the public resource allocation (e.g. funding) for supporting firms was regionally allocated and firms often accessed support from intermediaries within their close proximity. Thus, we selected two regions - the region of Scania in Sweden and North Rhine Westphalia in Germany - as our units of analysis. Sweden and Germany are interesting contexts because 
they have been consistently ranked among the top ten eco-innovative countries, which gives an indication about the quality of intermediation support available for firms (Eco-innovation Observatory, 2018). In addition, we had good contacts and access to information in the selected regions which is an essential requirement for case studies (Yin, 2017).

\section{Step 2 -Identify intermediaries in the context}

Within the regions, we focused on three kinds of intermediaries - agencies supporting companies with material and energy efficiency, business development organizations and cluster organizations. We focused on these types of intermediaries because they support firms with a wide array of intermediation roles such as financing, networking, fore-sighting and technical support, which are essential for developing an overview on intermediation in ecoinnovation compared to focusing on intermediaries with a narrow scope of activities e.g. bridging to funders. Interviews with experts, firms and information from industry and regional reports on innovation helped us to identify key intermediaries within the regions. This followed a chain referral sampling where interviewees suggested future interviewees from their acquaintances based on their relevance for the objectives of the study (cf. Biernacki and Waldorf, 1981). See Table 4 for an overview of the studied cases.

Table 4. Overview of studied intermediaries and interviewees (as of autumn 2014)

\begin{tabular}{|c|c|c|c|}
\hline $\begin{array}{l}\text { Region(s) and } \\
\text { document } \\
\text { analysed }\end{array}$ & $\begin{array}{l}\text { Name of } \\
\text { Intermediary }\end{array}$ & $\begin{array}{l}\text { Position of } \\
\text { Interviewee(s) }\end{array}$ & Information on intermediaries (as of autumn, 2014) \\
\hline $\begin{array}{l}\text { Scania, Sweden. } \\
\text { - Webpages } \\
\text { of studied } \\
\text { intermediari } \\
\text { es } \\
\text { Regional } \\
\text { innovation } \\
\text { reports for } \\
\text { region }\end{array}$ & $\begin{array}{l}\text { Sustainable } \\
\text { Business Hub }\end{array}$ & $\begin{array}{ll}\text { - } & \text { Project leader } \\
- \text { R\&D and } \\
\text { innovation } \\
\text { - } \\
\text { Business } \\
\text { developer }\end{array}$ & $\begin{array}{l}\text { Type of organization: Membership based, non-profit } \\
\text { organization } \\
\text { Size: } 6 \text { employees working full-time, } 130-\text { member } \\
\text { companies within the environmental goods and services } \\
\text { sector } \\
\text { Funding: Region Scania, European Union projects, } \\
\text { Private sources (e.g. membership fees) } \\
\text { Year established: } 2002 \\
\text { Scope of intermediation: Sweden, Region Scania }\end{array}$ \\
\hline $\begin{array}{l}\text { Scania, } \\
\text { Sweden } \\
\text { An } \\
\text { evaluation } \\
\text { report on the } \\
\text { activities of } \\
\text { Sustainable } \\
\text { Business }\end{array}$ & $\begin{array}{l}\text { Malmö } \\
\text { Cleantech City }\end{array}$ & $\begin{array}{ll}\text { - } & \text { Project } \\
\text { manager }\end{array}$ & $\begin{array}{l}\text { Type of organization: Non-membership-based } \\
\text { organization supporting companies mainly within the } \\
\text { environmental goods and services sector } \\
\text { Size: } 2 \text { employees working full-time } \\
\text { Funding: } 100 \% \text { from Malmö city } \\
\text { Year established: } 2010 \text { as a project } \\
\text { Scope of intermediation: Sweden, Malmö City }\end{array}$ \\
\hline $\begin{array}{l}\text { Hub by an } \\
\text { external } \\
\text { consultancy } \\
\text { An } \\
\text { Evaluation } \\
\text { report on the } \\
\text { activities of } \\
\text { Malmö }\end{array}$ & $\begin{array}{l}\text { Regional } \\
\text { council of } \\
\text { Scania }\end{array}$ & $\begin{array}{ll}\text { - } & \text { Development } \\
\text { manager } \\
\text { - } \\
\text { Business } \\
\text { manager }\end{array}$ & $\begin{array}{l}\text { Type of organization: Regional financer and } \\
\text { administrative authority for some intermediaries in } \\
\text { region Scania (e.g. Sustainable Business Hub) and } \\
\text { tasked with regional development } \\
\text { Funding: Public taxes } \\
\text { Year established: } 1999 \\
\text { Scope of intermediation: Sweden, Region Scania }\end{array}$ \\
\hline $\begin{array}{l}\text { Cleantech } \\
\text { City by an } \\
\text { external } \\
\text { consultancy } \\
\text { - Newsletters } \\
\text { of studied } \\
\text { intermediari }\end{array}$ & ALMI Scania & $\begin{array}{ll}\text { Innovation } \\
\text { advisor }\end{array}$ & $\begin{array}{l}\text { Type of organization: Non-membership based regional } \\
\text { branch of the national business development } \\
\text { organization with support targeted at all types of } \\
\text { companies } \\
\text { Size: } 26 \text { employees, a subsidiary to Almi } \\
\text { Företagspartner AB, owned by the Swedish government } \\
\text { Funding: parent company and regional owners (e.g. }\end{array}$ \\
\hline
\end{tabular}




\begin{tabular}{|c|c|c|c|}
\hline es & & & $\begin{array}{l}\text { regional councils) } \\
\text { Year established: parent company started in } 1994 \\
\text { Scope of intermediation: Sweden Region, Scania }\end{array}$ \\
\hline \multirow{5}{*}{$\begin{array}{l}\text { North Rhine } \\
\text { Westphalia, } \\
\text { Germany. } \\
\text { - Webpages } \\
\text { of studied } \\
\text { intermediari } \\
\text { es } \\
\text { A survey } \\
\text { report of } \\
\text { client } \\
\text { satisfaction } \\
\text { conducted } \\
\text { by an } \\
\text { external } \\
\text { consultancy } \\
\text { on the } \\
\text { Energy } \\
\text { Agency } \\
\text { A survey } \\
\text { conducted } \\
\text { by the } \\
\text { Federal } \\
\text { Ministry for } \\
\text { Economic } \\
\text { Affairs and } \\
\text { Energy on } \\
\text { energy } \\
\text { consulting } \\
\text { for SMEs } \\
\text { A survey } \\
\text { conducted } \\
\text { by the } \\
\text { climate } \\
\text { protection } \\
\text { agency, } \\
\text { region } \\
\text { Hannover on } \\
\text { initial } \\
\text { energy } \\
\text { consulting } \\
\text { for SMEs } \\
\text { A survey } \\
\text { conducted } \\
\text { by the } \\
\text { German } \\
\text { Environmen } \\
\text { t Ministry } \\
\text { on support } \\
\text { for Eco- } \\
\text { management } \\
\text { and Audit } \\
\text { Scheme }\end{array}$} & $\begin{array}{l}\text { The Greentech } \\
\text { Cluster }\end{array}$ & $\begin{array}{ll}- & \text { Principal } \\
- & \text { Innovation } \\
& \text { radar } \\
& \text { coordinator }\end{array}$ & $\begin{array}{l}\text { Type of organization: Non-membership-based cluster } \\
\text { initiative focused on the environmental goods and } \\
\text { services sector } \\
\text { Size: } 5-6 \text { employees working variably in time } \\
\text { Funding: Ministry of Environment, European Union } \\
\text { and regional development funds } \\
\text { Year established: } 2009 \\
\text { Scope of intermediation: Germany, North Rhine } \\
\text { Westphalia }\end{array}$ \\
\hline & $\begin{array}{l}\text { The Efficiency } \\
\text { Agency }\end{array}$ & $\begin{array}{l}\text { - Head of } \\
\text { consulting }\end{array}$ & $\begin{array}{l}\text { Type of organization: Government mandated } \\
\text { organization with technical experts on material and } \\
\text { energy efficiency in different sizes of companies and } \\
\text { sector } \\
\text { Size: } 30 \text { employees working full-time in six locations } \\
\text { Funding: Ministry of Environment, NRW } \\
\text { Year established: } 1998 \\
\text { Scope of intermediation: Germany, North Rhine } \\
\text { Westphalia }\end{array}$ \\
\hline & $\begin{array}{l}\text { The Energy } \\
\text { Agency }\end{array}$ & $\begin{array}{l}\text { Manager of } \\
\text { the } \\
\text { Department } \\
\text { for } \\
\text { Information } \\
\text { and Advice }\end{array}$ & $\begin{array}{l}\text { Type of organization: Government mandated } \\
\text { organization with technical experts on energy efficiency } \\
\text { in companies with different sizes and from different } \\
\text { sectors } \\
\text { Size: } 120 \text { employees working in Düsseldorf, } \\
\text { Gelsenkirchen and Wuppertal } \\
\text { Funding: state of North Rhine Westphalia, regional } \\
\text { development funds } \\
\text { Year established: } 1990 \\
\text { Scope of intermediation: Germany, North Rhine } \\
\text { Westphalia }\end{array}$ \\
\hline & $\begin{array}{l}\text { Agency for } \\
\text { business } \\
\text { promotions, } \\
\text { Duisburg }\end{array}$ & $\begin{array}{ll}\text { - } & \text { Two project } \\
\text { managers }\end{array}$ & $\begin{array}{l}\text { Type of organization: Shareholders are the city of } \\
\text { Duisburg }(50 \%) \text { and private companies }(50 \%) \text {. An } \\
\text { intermediary which supports different kinds of } \\
\text { companies } \\
\text { Size: } 20 \text { employees } \\
\text { Funding: City of Duisburg and private companies } \\
\text { Year established: } 1988 \\
\text { Scope of intermediation: Germany, North Rhine } \\
\text { Westphalia }\end{array}$ \\
\hline & $\begin{array}{l}\text { Essen } \\
\text { Economic } \\
\text { Development } \\
\text { Agency }\end{array}$ & $\begin{array}{ll}\text { Person } \\
\text { responsible } \\
\text { for energy, } \\
\text { water, and } \\
\text { environment }\end{array}$ & $\begin{array}{l}\text { Type of organization: } 50 \% \text { owned by the city of } \\
\text { Duisburg and } 50 \% \text { owned by association of businesses } \\
\text { e.g. utilities, savings banks, real estate companies. An } \\
\text { intermediary which supports different kinds of } \\
\text { companies } \\
\text { Size: } 30 \text { employees } \\
\text { Funding: } 95 \% \text { by city of Essen, association of } \\
\text { businesses } \\
\text { Year established: } 1991 \\
\text { Scope of intermediation: Germany, North Rhine } \\
\text { Westphalia }\end{array}$ \\
\hline
\end{tabular}


Step 3 - Map roles of the roles of intermediaries in eco-innovation

In Step 3, we focused on the support roles of the studied intermediaries in eco-innovation. The use of interviews and documentation studies proved useful to enable us to go deeper into the activities of the studied intermediaries. The interview questions allowed us to gather information on four main issues: (i) the intermediary organization (ii) the companies receiving support (iii) the support activities and roles and (vi) the outcomes of the support activities. Discussions about the organization itself focused on the driving force behind the entity and its strategies, and how these have changed over time. A discussion on their source of funding and human resources is also relevant since this influences the content and strategy of their intermediary roles and their survival as an entity over time (cf. Mignon and Kanda, 2018). The next set of questions focused on the clients of the intermediaries. Interview questions about the support activities focused on how new clients where approached, how the support activities were offered to clients (e.g. through newsletters, webpages, social meetings or workshops) and what specific support was given to companies interested in eco-innovation. After collecting information on the various activities of the intermediaries, the data were coded based on how well they matched with the comprehensive list of intermediation roles identified in previous literature (e.g. Howells, 2006; Kivimaa, 2014).

\section{Step 4 - Assess the roles of intermediaries}

Using the proposed assessment criteria, we made use of our collective interpretation of how well the intermediary roles contributed to the overall TIS functions based on their respective definitions. Table 5 provides an illustrative assessment based on our studied cases.

Table 5: Illustrative assessment of the potential contribution of intermediary roles to TIS functions

\begin{tabular}{|c|c|c|c|c|c|c|c|}
\hline & $\begin{array}{l}\text { Knowledge } \\
\text { development } \\
\text { and diffusion }\end{array}$ & $\begin{array}{l}\text { Guidance of } \\
\text { the search }\end{array}$ & $\begin{array}{l}\text { Entrepreneurial } \\
\text { experimentation }\end{array}$ & $\begin{array}{l}\text { Market } \\
\text { formation }\end{array}$ & $\begin{array}{l}\text { Development } \\
\text { of positive } \\
\text { externalities }\end{array}$ & Legitimation & $\begin{array}{l}\text { Resource } \\
\text { mobilization }\end{array}$ \\
\hline $\begin{array}{l}\text { Sustainable } \\
\text { Business Hub }\end{array}$ & $\begin{array}{l}\text { (Not } \\
\text { detected) }\end{array}$ & $\begin{array}{l}\text { (Not } \\
\text { detected) }\end{array}$ & $\begin{array}{l}\text { Providing } \\
\text { matchmaking } \\
\text { opportunities } \\
\text { for member } \\
\text { companies to } \\
\text { demonstrate and } \\
\text { test their new } \\
\text { products and } \\
\text { services for } \\
\text { further } \\
\text { development } \\
\text { and publicity. } \\
\text { (Medium) }\end{array}$ & $\begin{array}{l}\text { Providing } \\
\text { support for } \\
\text { members } \\
\text { companies to } \\
\text { develop a } \\
\text { strong position } \\
\text { on the } \\
\text { domestic and } \\
\text { export market } \\
\text { through trade } \\
\text { visits, business } \\
\text { coaching, and } \\
\text { matchmaking } \\
\text { activities. } \\
\text { (Medium) }\end{array}$ & $\begin{array}{l}\text { (Not } \\
\text { detected) }\end{array}$ & $\begin{array}{l}\text { Raising public } \\
\text { awareness for } \\
\text { eco-innovation } \\
\text { through } \\
\text { networking, } \\
\text { innovation } \\
\text { contests, } \\
\text { testing and } \\
\text { demonstration } \\
\text { activities. } \\
\text { (Medium) }\end{array}$ & $\begin{array}{l}\text { Serving as a } \\
\text { bridge between } \\
\text { member } \\
\text { companies and } \\
\text { other } \\
\text { organizations to } \\
\text { access knowledge, } \\
\text { networks and } \\
\text { financial resources } \\
\text { needed for eco- } \\
\text { innovation. } \\
\text { (Strong) }\end{array}$ \\
\hline $\begin{array}{l}\text { Malmö } \\
\text { Cleantech } \\
\text { City }\end{array}$ & $\begin{array}{l}\text { (Not } \\
\text { detected) }\end{array}$ & $\begin{array}{l}\text { (Not } \\
\text { detected) }\end{array}$ & $\begin{array}{l}\text { Proving test bed } \\
\text { for companies } \\
\text { in the early } \\
\text { phase of } \\
\text { innovation to } \\
\text { test and } \\
\text { evaluate their } \\
\text { products and } \\
\text { services for } \\
\text { further } \\
\text { development } \\
\text { and also to gain }\end{array}$ & $\begin{array}{l}\text { Providing } \\
\text { support for } \\
\text { companies to } \\
\text { establish a } \\
\text { strong market } \\
\text { position in the } \\
\text { city of Malmö } \\
\text { through } \\
\text { matchmaking } \\
\text { activities. } \\
\text { (Medium) }\end{array}$ & $\begin{array}{l}\text { (Not } \\
\text { detected) }\end{array}$ & $\begin{array}{l}\text { Promoting the } \\
\text { environmental } \\
\text { goods and } \\
\text { services sector } \\
\text { as a major } \\
\text { source of eco- } \\
\text { innovation. } \\
\text { (Medium) }\end{array}$ & $\begin{array}{l}\text { Serving as a } \\
\text { bridge between } \\
\text { companies and } \\
\text { other } \\
\text { organizations such } \\
\text { as universities, the } \\
\text { city of Malmö to } \\
\text { access knowledge } \\
\text { related to business } \\
\text { competence } \\
\text { development, } \\
\text { networks, potential }\end{array}$ \\
\hline
\end{tabular}




\begin{tabular}{|c|c|c|c|c|c|c|c|}
\hline & & & $\begin{array}{l}\text { publicity. } \\
\text { (Medium) }\end{array}$ & & & & $\begin{array}{l}\text { customers and } \\
\text { suppliers, and } \\
\text { financing. } \\
\text { (Strong) }\end{array}$ \\
\hline ALMI Scania & $\begin{array}{l}\text { (Not } \\
\text { detected) }\end{array}$ & $\begin{array}{l}\text { (Not } \\
\text { detected) }\end{array}$ & $\begin{array}{l}\text { ALMI offers } \\
\text { free counselling } \\
\text { under secrecy to } \\
\text { entrepreneurs } \\
\text { on exploring } \\
\text { business } \\
\text { concepts into } \\
\text { successful } \\
\text { businesses with } \\
\text { growth } \\
\text { potential. } \\
\text { (Medium) }\end{array}$ & $\begin{array}{l}\text { (Not } \\
\text { detected) }\end{array}$ & $\begin{array}{l}\text { (Not } \\
\text { detected) }\end{array}$ & $\begin{array}{l}\text { (Not } \\
\text { detected) }\end{array}$ & $\begin{array}{l}\text { ALMI offers } \\
\text { financial support } \\
\text { for preliminary } \\
\text { studies in the form } \\
\text { of a grant which } \\
\text { can be used to } \\
\text { build a prototype, } \\
\text { file a patent } \\
\text { application, } \\
\text { external } \\
\text { verification or } \\
\text { participation at a } \\
\text { fair. } \\
\text { ALMI offers loans } \\
\text { to companies to } \\
\text { assist them in their } \\
\text { business } \\
\text { development. } \\
\text { ALMI serves as a } \\
\text { bridge between } \\
\text { entrepreneurs and } \\
\text { other support } \\
\text { actors such as } \\
\text { cluster initiatives } \\
\text { and universities, if } \\
\text { particular kinds of } \\
\text { support (e.g. eco- } \\
\text { innovation } \\
\text { knowledge) is } \\
\text { needed and not } \\
\text { available in-house. } \\
\text { (Strong) }\end{array}$ \\
\hline $\begin{array}{l}\text { The } \\
\text { Greentech } \\
\text { Cluster }\end{array}$ & $\begin{array}{l}\text { (Not } \\
\text { detected) }\end{array}$ & $\begin{array}{l}\text { Forecasting } \\
\text { an annual list } \\
\text { of cutting- } \\
\text { edge eco- } \\
\text { innovations } \\
\text { and bringing } \\
\text { together } \\
\text { stakeholders } \\
\text { such as } \\
\text { companies, } \\
\text { policy } \\
\text { makers, } \\
\text { researchers } \\
\text { and funders } \\
\text { to develop it } \\
\text { further. } \\
\text { (Strong) }\end{array}$ & $\begin{array}{l}\text { (Not } \\
\text { detected) }\end{array}$ & $\begin{array}{l}\text { (Not } \\
\text { detected) }\end{array}$ & $\begin{array}{l}\text { (Not } \\
\text { detected) }\end{array}$ & $\begin{array}{l}\text { Promoting the } \\
\text { environmental } \\
\text { goods and } \\
\text { services sector } \\
\text { as a major } \\
\text { source of eco- } \\
\text { innovation. } \\
\text { (Medium) }\end{array}$ & $\begin{array}{l}\text { Providing arenas } \\
\text { to facilitate } \\
\text { collaborations } \\
\text { between } \\
\text { companies and key } \\
\text { stakeholders to } \\
\text { access networks, } \\
\text { finance, and } \\
\text { knowledge for } \\
\text { eco-innovation. } \\
\text { (Strong) }\end{array}$ \\
\hline $\begin{array}{l}\text { The } \\
\text { Efficiency } \\
\text { Agency }\end{array}$ & $\begin{array}{l}\text { (Not } \\
\text { detected) }\end{array}$ & $\begin{array}{l}\text { (Not } \\
\text { detected) }\end{array}$ & $\begin{array}{l}\text { (Not } \\
\text { detected) }\end{array}$ & $\begin{array}{l}\text { (Not } \\
\text { detected) }\end{array}$ & $\begin{array}{l}\text { (Not } \\
\text { detected) }\end{array}$ & $\begin{array}{l}\text { Information } \\
\text { dissemination } \\
\text { to raise } \\
\text { awareness on } \\
\text { the economic } \\
\text { and } \\
\text { environmental } \\
\text { benefits of } \\
\text { cleaner } \\
\end{array}$ & $\begin{array}{l}\text { Providing } \\
\text { information and } \\
\text { assisting } \\
\text { companies with } \\
\text { financial } \\
\text { applications to } \\
\text { implement } \\
\text { resource efficiency } \\
\text { projects. }\end{array}$ \\
\hline
\end{tabular}




\begin{tabular}{|c|c|c|c|c|c|c|c|}
\hline & & & & & & $\begin{array}{l}\text { production } \\
\text { activities } \\
\text { among } \\
\text { different } \\
\text { stakeholders. } \\
\text { (Medium) }\end{array}$ & $\begin{array}{l}\text { Providing arenas } \\
\text { to facilitate } \\
\text { collaborations } \\
\text { between } \\
\text { companies and } \\
\text { other stakeholders } \\
\text { to access } \\
\text { knowledge, and } \\
\text { networks for } \\
\text { resource efficiency } \\
\text { projects. } \\
\text { Providing } \\
\text { technical expertise } \\
\text { on energy and } \\
\text { material } \\
\text { efficiency, and } \\
\text { their related } \\
\text { project } \\
\text { implementation. } \\
\text { (Strong) }\end{array}$ \\
\hline $\begin{array}{l}\text { The Energy } \\
\text { Agency }\end{array}$ & $\begin{array}{l}\text { (Not } \\
\text { detected) }\end{array}$ & $\begin{array}{l}\text { (Not } \\
\text { detected) }\end{array}$ & $\begin{array}{l}\text { In collaboration } \\
\text { with other } \\
\text { agencies, the } \\
\text { Energy Agency } \\
\text { is responsible } \\
\text { for climate } \\
\text { protection } \\
\text { activities within } \\
\text { a network for } \\
\text { renewable } \\
\text { energy } \\
\text { technologies to } \\
\text { initiate } \\
\text { innovative } \\
\text { products and } \\
\text { services, speed } \\
\text { up their market } \\
\text { readiness and } \\
\text { exploit their } \\
\text { economic } \\
\text { potential, } \\
\text { including } \\
\text { export. } \\
\text { (Strong) }\end{array}$ & $\begin{array}{l}\text { (Not } \\
\text { detected) }\end{array}$ & $\begin{array}{l}\text { (Not } \\
\text { detected) }\end{array}$ & $\begin{array}{l}\text { Information } \\
\text { dissemination } \\
\text { to raise } \\
\text { awareness on } \\
\text { the economic } \\
\text { and } \\
\text { environmental } \\
\text { benefits of } \\
\text { energy } \\
\text { efficiency } \\
\text { activities } \\
\text { among } \\
\text { different } \\
\text { stakeholders. } \\
\text { (Medium) }\end{array}$ & $\begin{array}{l}\text { Giving advice to } \\
\text { companies on how } \\
\text { to find funding to } \\
\text { implement energy } \\
\text { efficiency } \\
\text { measures. } \\
\text { Providing } \\
\text { continuous } \\
\text { training and } \\
\text { information to } \\
\text { companies on } \\
\text { energy efficiency } \\
\text { solutions and } \\
\text { energy weak spots } \\
\text { in buildings and } \\
\text { production } \\
\text { processes. } \\
\text { The energy agency } \\
\text { serves as a contact } \\
\text { organization } \\
\text { regarding energy } \\
\text { research in the } \\
\text { region and works } \\
\text { to advance } \\
\text { collaboration } \\
\text { between research } \\
\text { and industry. } \\
\text { (Strong) }\end{array}$ \\
\hline $\begin{array}{l}\text { Agency for } \\
\text { business } \\
\text { promotions, } \\
\text { Duisburg }\end{array}$ & $\begin{array}{l}\text { (Not } \\
\text { detected) }\end{array}$ & $\begin{array}{l}\text { (Not } \\
\text { detected) }\end{array}$ & $\begin{array}{l}\text { (Not } \\
\text { detected) }\end{array}$ & $\begin{array}{l}\text { (Not } \\
\text { detected) }\end{array}$ & $\begin{array}{l}\text { (Not } \\
\text { detected) }\end{array}$ & $\begin{array}{l}\text { Gathering and } \\
\text { disseminating } \\
\text { information to } \\
\text { companies on } \\
\text { the economic } \\
\text { benefits of } \\
\text { participation } \\
\text { in material and } \\
\text { energy saving } \\
\text { programs. }\end{array}$ & $\begin{array}{l}\text { Serving as a } \\
\text { bridge for } \\
\text { companies to } \\
\text { access } \\
\text { information, } \\
\text { funding and } \\
\text { knowledge from } \\
\text { other } \\
\text { organizations. } \\
\text { Providing arenas }\end{array}$ \\
\hline
\end{tabular}




\begin{tabular}{|c|c|c|c|c|c|c|c|}
\hline & & & & & & $\begin{array}{l}\text { Acting as a } \\
\text { meeting point } \\
\text { between } \\
\text { companies and } \\
\text { public } \\
\text { organizations } \\
\text { regarding } \\
\text { energy and } \\
\text { material } \\
\text { efficiency e.g. } \\
\text { new } \\
\text { regulations } \\
\text { (Medium) }\end{array}$ & $\begin{array}{l}\text { to facilitate eco- } \\
\text { innovation using } \\
\text { education, as well } \\
\text { as customized } \\
\text { problem solving to } \\
\text { improve eco- } \\
\text { efficiency of } \\
\text { processes, } \\
\text { products, } \\
\text { practices, and } \\
\text { services in } \\
\text { organizations - } \\
\text { Ecoprofit. } \\
\text { (Strong) }\end{array}$ \\
\hline $\begin{array}{l}\text { Essen } \\
\text { Economic } \\
\text { Development } \\
\text { Agency }\end{array}$ & $\begin{array}{l}\text { (Not } \\
\text { detected) }\end{array}$ & $\begin{array}{l}\text { (Not } \\
\text { detected) }\end{array}$ & $\begin{array}{l}\text { (Not } \\
\text { detected) }\end{array}$ & $\begin{array}{l}\text { Serving as a } \\
\text { link between } \\
\text { companies and } \\
\text { export markets } \\
\text { through trade } \\
\text { visits and } \\
\text { matchmaking } \\
\text { activities. } \\
\text { (Medium) }\end{array}$ & $\begin{array}{l}\text { (Not } \\
\text { detected) }\end{array}$ & $\begin{array}{l}\text { Organising } \\
\text { events to } \\
\text { disseminate } \\
\text { information on } \\
\text { energy and } \\
\text { material } \\
\text { efficiency in } \\
\text { different } \\
\text { production } \\
\text { processes. } \\
\text { (Medium) }\end{array}$ & $\begin{array}{l}\text { Serving as a } \\
\text { bridge for } \\
\text { companies to } \\
\text { access } \\
\text { information, } \\
\text { funding and } \\
\text { networks from } \\
\text { other } \\
\text { organizations } \\
\text { relevant for eco- } \\
\text { innovation. } \\
\text { The organization } \\
\text { uses networks with } \\
\text { other public } \\
\text { support agencies } \\
\text { to deliver specific } \\
\text { eco-innovation } \\
\text { support to } \\
\text { companies on } \\
\text { energy or material } \\
\text { efficiency. } \\
\text { (Strong) }\end{array}$ \\
\hline
\end{tabular}

\section{Discussion}

Recommendations can be made for intermediaries and their key stakeholders based on the outcome of the assessment. However, caution should be taken when interpreting the outcome of the assessment since different types of intermediaries operate in different contexts and, thus, it is challenging to benchmark and establish an optimal level of intermediary contribution to TIS functions. Furthermore, intermediaries are actors within a broader innovation system and thus findings on the contribution of intermediaries' roles to TIS functions should be interpreted within a broader innovation system context.

From our case studies, we identified some intermediary roles that relate to the TIS functions guidance of the search, entrepreneurial experimentation, market formation, legitimation and resource mobilization. In guidance of the search, an intermediary generates an eco-innovation foresight and roadmap and brings together different stakeholders to develop it further. This role is essential in facilitating eco-innovation since it provides direction for learning and exploration shared by many stakeholders, attracts attention and social acceptance for the ecoinnovation (cf. Kivimaa, 2014). Furthermore, intermediaries contributing to entrepreneurial experimentation are actively involved in creating conditions for learning by doing and using including testing, validation and training. In doing so, intermediaries provide test bed for firms in the early phase of innovation to test and evaluate their products and services for further development and also to gain publicity. Intermediaries also facilitate technology 
networks to develop innovative products and services, speed up their market readiness and exploit their market potential including export. Though entrepreneurial experimentation is primarily targeted at probing into new technologies and their applications to reduce uncertainty (cf. Bergek et al., 2008), the related intermediation activities such as testing, evaluation and validation can also provide publicity, and contribute to the societal acceptance of particular eco-innovations. Furthermore, since eco-innovations compete with conventional innovations to perform similar functions with a lower environmental impact (CarrilloHermosilla et al., 2010), intermediaries supporting eco-innovations dedicate an important part of their activities to legitimation (i.e. social acceptance and compliance with relevant institutions). In doing so, intermediation roles include branding eco-innovations, providing publicity and building public trust through activities such as demonstration and experimentation projects in living labs and test beds where the environmental benefits of such innovations can be validated. Legitimation is particularly important for resource mobilization, for demand formation and for actors related to a particular innovation to gain political strength (cf. Bergek et al., 2008). When contributing to market formation, intermediaries undertake activities to accelerate the application and commercialisation of new technologies using business coaching, matchmaking and trade visits. A particularly strong activity among the studied intermediaries is their contribution to resource mobilization. This was undertaken through their role as providers of in-house resources such as funding, networks and technical expertise, in addition to their important role in bridging access to such resources from other organizations such as banks, clusters, and universities. Mobilizing resources through bridging activities is a core intermediation activity since intermediaries are often defined by their "inbetweenness" and boundary spanning activities between different organisations (Moss, 2009).

It should however be mentioned that, as with any case studies, the intermediaries that we studied influenced the kinds of contributions to TIS functions that we identified a priori. Thus, other kinds of contributions to TIS functions can be identified when different types of intermediaries and actors (e.g. universities and research institutes) are studied. For example, systemic intermediaries i.e. intermediaries that operate in networks instead of one-to-one intermediation have the capacity, mandate and objective to influence entire innovation systems (van Lente et al., 2003). Thus, such systemic intermediaries would have different contributions compared to the cases that we studied which can be regarded as (eco)innovation intermediaries (cf. Howells, 2006). Furthermore, our results also suggest that intermediaries may not contribute equally to all the system functions and thus may be better suited for certain purposes. For example, Nilsson and Sia-Ljungström (2013) show that intermediaries have a high concentration of activities designed to promote the functions of market identification and formation, legitimation and facilitation/creation of synergies for resource mobilization. From this discussion, it is imperative for researchers to be transparent in their analysis regarding the type of intermediary and the contexts since intermediaries in general cannot be lumped together as one coherent group.

Finally, the operationalization of the analytical approach reveals certain challenges which need to be addressed and highlights aspects of the analytical approach which can be improved through further research. An overall challenge relates to the use of expert opinion in the analytical approach. This implies that the outcome of the assessment is dependent on the knowledge of the expert group. Thus, there is a risk that outcomes of the assessment can differ between different expert groups. There is a therefore the need for methodological developments to ensure consistent results between different expert groups. In addition, the assessment is time and resource intensive because it includes several steps, iterations between these steps, and preparations for these steps through data and information gathering. Thus, 
gathering a well-represented group of experts in a workshop together with learning between subsequent assessments is a plausible approach for an efficient and effective use of resources.

With regards to challenges in the specific steps of the analytical approach, in Step 1, defining the context of intermediation represented an important choice. In our empirical study defining the context within which the intermediary operates was quite straightforward because of our focus on intermediaries within a region who supported firms in eco-innovation and our access to information in these regions. However, we experienced particular challenges in Step 2, identifying intermediaries within a selected region. Particularly, it was anticipated that identifying intermediaries would be a serious challenge, given that the literature lacks consensus on their definition together with the very broad definitions of intermediaries provided in the literature (e.g. Howells, 2006). Furthermore, this step was challenging since we had to collect extensive information and develop in-depth understanding on the activities of the various actors in the region to be able to identify potential intermediaries and intermediation activities. As stressed in section 2, rigorously specifying which types of intermediaries are studied, their scope and context of intermediation is advisable. With respect to Step 3, a main practical challenge is to identify the support roles of the studied intermediaries in eco-innovation. Coding the activities of the intermediaries by using the intermediation roles identified in previous contributions can be challenging because of the different list of roles in the literature and their different foci (e.g. Howells, 2006; Kivimaa, 2014; Kanda et al., 2018). This can lead to some confusion and redundancy (cf. Klekx and Leeuwis, 2009). Thus, an analyst has to be transparent with regard to which list of roles is used in the coding of the empirical data based on the types of intermediaries being analysed. With regards to Step 4, our empirical study suggested that engaging experts to identify how the roles of the intermediaries contributed to TIS functions is a reasonable methodological choice. However, this qualitative assessment is unavoidably subjective and a more "objective" procedure seems advisable. To increase transparency in the current approach, proper documentation of the assessment including remarks should be made available to allow review and further development. From our experience, relying on workshops in which experts discuss among themselves and come to a consensus regarding the contribution of intermediary roles to TIS functions is currently a plausible approach given the theoretical linkage and qualitative nature of the assessment.

Finally, the interpretation of the outcome of the assessment to provide recommendations for stakeholders in Step 5 can also be a difficult task, as the intermediaries are actors within a broader innovation system and thus there are challenges regarding attributional issues, interaction between intermediaries and how the results should be interpreted vis a vis the context and its specificities. To be able to provide robust recommendations to key stakeholders, there is a need to consider the context within which the assessment is conducted and how that influences the impact of intermediaries. Furthermore, even though the functional analysis is central in the approach, finding a way to integrate structural aspects could make the approach even more powerful since the roles that intermediaries undertake and the extent to which such roles potentially impact the system-level is dependent on structural aspects such as their source and size of funding, governance structure and number of employees (cf. Mignon and Kanda, 2018).

\section{Conclusions and further research}

The aim of this article was to develop and operationalize an approach for analysing the roles of intermediaries in eco-innovation and their contribution to innovation systems. The allure of 
the analytical approach is that, it encourages analyst to make a transparent analytical distinction between different types of intermediaries, their intermediation roles and their potential contributions to innovation system functions. The analytical approach provides first steps towards conceptualising and empirically demonstrating the impact of intermediaries beyond individual projects and firms. However, in order to interpret the outcomes of the assessment, caution should be exercised since different kinds of actors including intermediaries exist within an innovation system. Thus, the interpretation of the outcomes of the assessment should be based on the characteristics of the intermediaries and the broader innovation system. The analytical approach also provides the opportunity to analyse the contribution of intermediaries to the innovation system both as individual entities and as a group of intermediaries within a given scope. Altogether, our findings suggest that there is indeed an interest for policy makers to strengthen the role of intermediaries in innovation systems as they contribute in one way or the other to some of the innovation system functions. Further investigations should seek to understand not only the extent to which the roles of intermediaries contribute to these innovation system functions but also the magnitude, the type of interaction and the indirect effects these activities can have on the innovation system. Since the approach relies on expert opinion for the assessment, further research should be devoted to incorporate both qualitative and quantitative data on the contribution of intermediaries to the innovation system. Finally, this article has provided an ex ante analysis of how intermediaries can contribute to the TIS functions. Future research efforts should be dedicated to assess whether the intermediaries have contributed to the fulfilment of TIS functions, i.e. their actual performance in a particular setting (ex-post analysis). This would require building a methodology (e.g., indicators) and carrying out empirical studies to analyse such contribution.

\section{Acknowledgements}

Financial support for this article came from Formas (The Swedish Research Council for Environment, Agricultural Sciences and Spatial Planning) through ECO-INOVERA project "SHIFT" and the European Union Regional Development fund through the Interreg project "SUPER". Earlier drafts of this article have been presented at three international conferences - The 18th Annual Interdisciplinary Entrepreneurship Conference, November 13-14th, 2014, Oldenburg, Germany; The Global Cleaner Production and Sustainable Consumption Conference, November 1-4, 2015, Sitges-Barcelona, Spain; The 8th International Sustainability Transitions Conference, June 18-21, 2017, Gothenburg, Sweden.

\section{References}

Bergek, A., Jacobsson, S., Carlsson, B., Lindmark, S., Rickne, A., 2008. Analyzing the functional dynamics of technological innovation systems: A scheme of analysis. Research Policy 37, 407-429. https://doi.org/10.1016/j.respol.2007.12.003

Biernacki, P., Waldorf, D., 1981. Snowball sampling: Problems and techniques of chain referral sampling. Sociological methods \& research 10, 141-163.

Bleda, M., del Río, P., 2013. The market failure and the systemic failure rationales in technological innovation systems. Research Policy 42, 1039-1052. https://doi.org/10.1016/j.respol.2013.02.008

Carlsson, B., Jacobsson, S., Holmén, M., Rickne, A., 2002. Innovation systems: analytical and methodological issues. Research policy 31, 233-245. 
Carlsson, B., Stankiewicz, R., 1991. On the nature, function and composition of technological systems. Journal of evolutionary economics 1, 93-118.

Carrillo-Hermosilla, J., del Río, P., Könnölä, T., 2010. Diversity of eco-innovations: Reflections from selected case studies. Journal of Cleaner Production 18, 1073-1083. https://doi.org/10.1016/j.jclepro.2010.02.014

Cohen, B., Winn, M.I., 2007. Market imperfections, opportunity and sustainable entrepreneurship. Journal of Business Venturing 22, 29-49.

De Marchi, V., 2012. Environmental innovation and R\&D cooperation: Empirical evidence from Spanish manufacturing firms. Research Policy 41, 614-623.

De Silva, M., Howells, J., Meyer, M., 2018. Innovation intermediaries and collaboration: Knowledge-based practices and internal value creation. Research Policy 47, 70-87. https://doi.org/10.1016/j.respol.2017.09.011

del Río, P., Bleda, M., 2012. Comparing the innovation effects of support schemes for renewable electricity technologies: A function of innovation approach. Energy Policy $50,272-282$.

del Río, P., Peñasco, C., Romero-Jordán, D., 2016. What drives eco-innovators? A critical review of the empirical literature based on econometric methods. Journal of Cleaner Production 112, 2158-2170. https://doi.org/10.1016/j.jclepro.2015.09.009

Eco-innovation Observatory, 2018. EU Eco-innovation Scoreboard.

Fichter, K., Faud-Luke, A., Klofsten, M., 2013. Support Systems for Sustainable Entrepreneurship and Transformation (SHIFT). Work Package, 1.

Foxon, T., Andersen, M.M., 2009. The greening of innovation systems for eco-innovationtowards an evolutionary climate mitigation policy. Presented at the DRUID Summer Conference-Innovation, Strategy and Knowledge.

Geels, F.W., 2011. The multi-level perspective on sustainability transitions: Responses to seven criticisms. Environmental Innovation and Societal Transitions 1, 24-40. https://doi.org/10.1016/j.eist.2011.02.002

Geissdoerfer, M., Savaget, P., Bocken, N.M.P., Hultink, E.J., 2017. The Circular Economy A new sustainability paradigm? Journal of Cleaner Production 143, 757-768. https://doi.org/10.1016/j.jclepro.2016.12.048

Gliedt, T., Hoicka, C.E., Jackson, N., 2018. Innovation intermediaries accelerating environmental sustainability transitions. Journal of Cleaner Production 174, 12471261. https://doi.org/10.1016/j.jclepro.2017.11.054

Hekkert, M.P., Negro, S.O., 2009. Functions of innovation systems as a framework to understand sustainable technological change: Empirical evidence for earlier claims. Technological forecasting and social change 76, 584-594.

Hekkert, M.P., Suurs, R.A.A., Negro, S.O., Kuhlmann, S., Smits, R.E.H.M., 2007. Functions of innovation systems: A new approach for analysing technological change. Technological Forecasting and Social Change 74, 413-432. https://doi.org/10.1016/j.techfore.2006.03.002

Hjelm, O., Lindahl, M., 2016. Roles of Academia in Supporting Eco-Design in Small Companies for Better Environmental and Economic Performance. Procedia CIRP 50, $745-750$. 
Hojnik, J., Ruzzier, M., 2016. What drives eco-innovation? A review of an emerging literature. Environmental Innovation and Societal Transitions 19, 31-41.

Horbach, J., 2008. Determinants of environmental innovation-New evidence from German panel data sources. Research policy 37, 163-173.

Howells, J., 2006. Intermediation and the role of intermediaries in innovation. Research Policy 35, 715-728. https://doi.org/10.1016/j.respol.2006.03.005

Hyysalo, S., Johnson, M., Juntunen, J.K., 2017. The diffusion of consumer innovation in sustainable energy technologies. Journal of Cleaner Production 162, S70-S82.

Jaffe, A.B., Newell, R.G., Stavins, R.N., 2005. A tale of two market failures: Technology and environmental policy. Ecological Economics 54, 164-174. https://doi.org/10.1016/j.ecolecon.2004.12.027

Kanda, W., Hjelm, O., Clausen, J., Bienkowska, D., 2018. Roles of intermediaries in supporting eco-innovation. Journal of Cleaner Production 205, 1006-1016.

Keskin, D., Diehl, J.C., Molenaar, N., 2013. Innovation process of new ventures driven by sustainability. Journal of Cleaner Production 45, 50-60. https://doi.org/10.1016/j.jclepro.2012.05.012

Kiefer, C.P., Del Río González, P., Carrillo-Hermosilla, J., 2018. Drivers and barriers of eco-innovation types for sustainable transitions: A quantitative perspective. Business Strategy and the Environment.

Kivimaa, P., 2014. Government-affiliated intermediary organisations as actors in system-level transitions. Research Policy 43, 1370-1380. https://doi.org/10.1016/j.respol.2014.02.007

Kivimaa, P., Boon, W., Antikainen, R., 2017. Commercialising university inventions for sustainability - a case study of (non-)intermediating 'cleantech' at Aalto University. Science and Public Policy 44, 631-644. https://doi.org/10.1093/scipol/scw090

Kivimaa, P., Boon, W., Hyysalo, S., Klerkx, L., 2019. Towards a typology of intermediaries in sustainability transitions: a systematic review and a research agenda. Research Policy 48, 1062-1075.

Kivimaa, P., Boon, W., Hyysalo, S., Klerkx, L., 2018. Towards a typology of intermediaries in sustainability transitions: A systematic review and a research agenda. Research Policy.

Klerkx, L., Leeuwis, C., 2009. Establishment and embedding of innovation brokers at different innovation system levels: Insights from the Dutch agricultural sector. Technological Forecasting and Social Change 76, 849-860. https://doi.org/10.1016/j.techfore.2008.10.001

Klewitz, Zeyen, Anica, Hansen, Erik G., 2012. Intermediaries driving eco-innovation in SMEs: a qualitative investigation. Euro Jrnl of Inn Mnagmnt 15, 442-467. https://doi.org/10.1108/14601061211272376

Lukkarinen, J., Berg, A., Salo, M., Tainio, P., Alhola, K., Antikainen, R., 2018. An intermediary approach to technological innovation systems (TIS)-The case of the cleantech sector in Finland. Environmental Innovation and Societal Transitions 26, 136-146. https://doi.org/10.1016/j.eist.2017.04.003

Markard, J., 2018. The life cycle of technological innovation systems. Technological Forecasting and Social Change. 
Markard, J., Truffer, B., 2008. Technological innovation systems and the multi-level perspective: Towards an integrated framework. Research policy 37, 596-615.

Marzucchi, A., Montresor, S., 2017. Forms of knowledge and eco-innovation modes: Evidence from Spanish manufacturing firms. Ecological Economics 131, 208-221. https://doi.org/10.1016/j.ecolecon.2016.08.032

Mignon, I., Kanda, W., 2018. A typology of intermediary organizations and their impact on sustainability transition policies. Environmental Innovation and Societal Transitions 29, 100-113.

Moss, T., 2009. Intermediaries and the governance of sociotechnical networks in transition. Environment and Planning A 41, 1480-1495.

Nilsson, M., Sia-Ljungström, C., 2013. The Role of Innovation Intermediaries in Innovation Systems. Proceedings in Food System Dynamics 160-180.

Polzin, F., von Flotow, P., Klerkx, L., 2016. Addressing barriers to eco-innovation: Exploring the finance mobilisation functions of institutional innovation intermediaries. Technological Forecasting and Social Change 103, 34-46. https://doi.org/10.1016/j.techfore.2015.10.001

Rennings, K., 2000. Redefining innovation - eco-innovation research and the contribution from ecological economics. Ecological Economics 32, 319-332. https://doi.org/10.1016/S0921-8009(99)00112-3

Smith, A., Hargreaves, T., Hielscher, S., Martiskainen, M., Seyfang, G., 2016. Making the most of community energies: Three perspectives on grassroots innovation. Environment and Planning A 48, 407-432.

van Lente, H., Hekkert, M., Smits, R., van Waveren, B., 2003. Roles of Systemic Intermediaries in Transition Processes. Int. J. Innov. Mgt. 07, 247-279. https://doi.org/10.1142/S1363919603000817

Yin, R.K., 2017. Case study research and applications: Design and methods. Sage publications. 